\title{
FOOD SELF-PROVISIONING IN THE CZECH REPUBLIC - A COMPARISON OF SUBURBAN AND PERIPHERAL REGIONS OF RURAL SOUTH MORAVIA
}

Ilona Svobodová, Jan Drlík, Daniela Spěšná, Miloslav Delín ${ }^{1}$

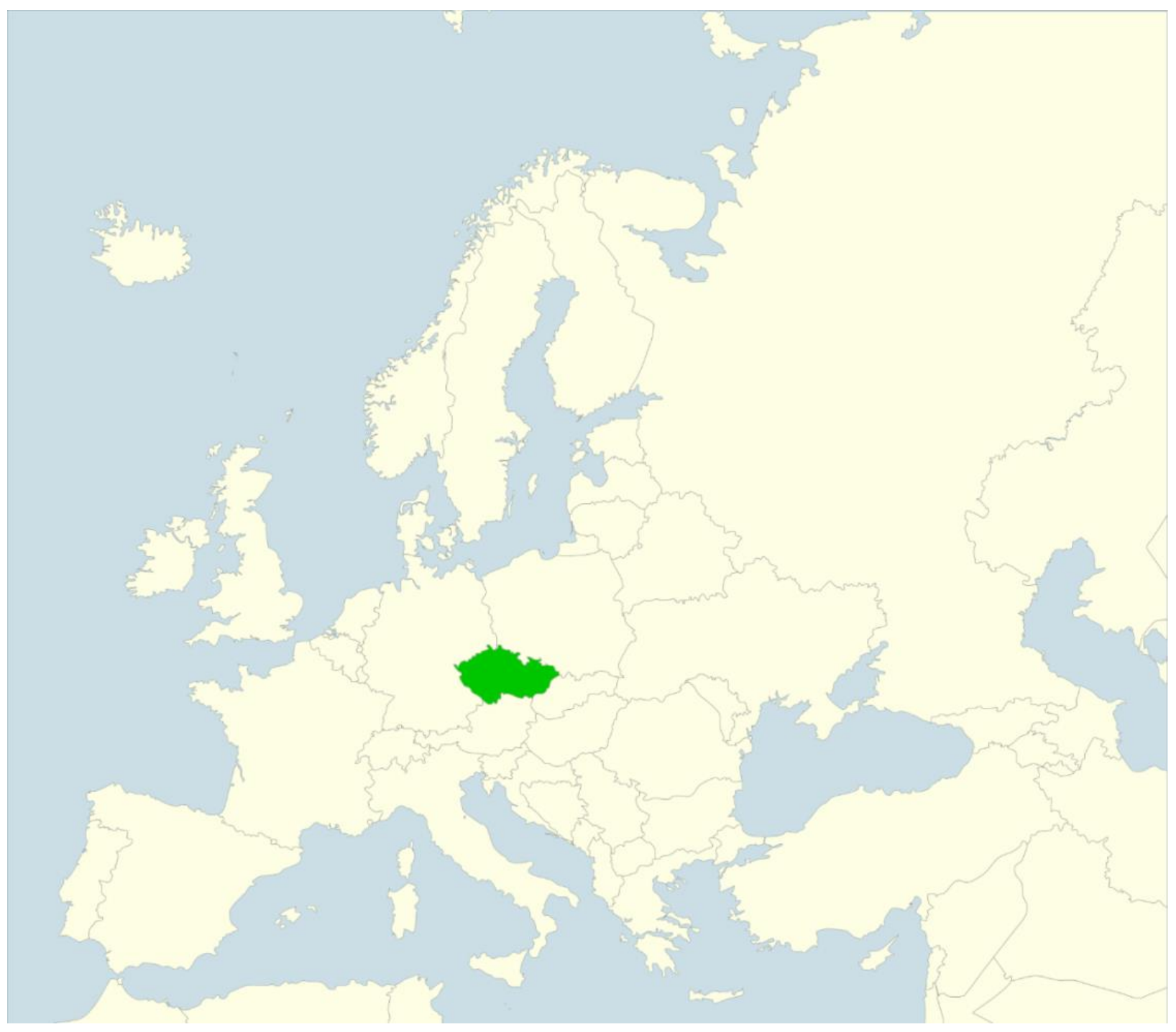

1 Mgr. Ilona Svobodová, Ph.D., e-mail: svobodova.ilona@uzei.cz, Ing. Jan Drlík, e-mail: drlik.jan@uzei.cz, PhDr. Daniela Spěšná, e-mail: spesna.daniela@uzei.cz, Mgr. Miloslav Delín, e-mail: delin.miloslav@uzei.cz; Institute of Agricultural Economics and Information. Prague, Czechia, Office Brno 
Abstract: The Czech Republic ranks among the countries with a strong tradition of home food self-provisioning. In this article, we focused our attention specifically to the traditional and frequently neglected phenomenon of rural self-provisioning while newly introducing a data-based analysis of the phenomenon in two areas, i.e., suburbs and peripheries of the South Moravian region. Unlike the research carried out in the CR or EU to date, our survey aims exclusively at the analysis of households with access to land, which allow a more detailed scrutiny of growing a wide range of commodities, the attitudes to it and its perspectives. The results of the field study carried out in 178 rural households in two types of South Moravian regions (suburban and peripheral) from 2017 show the regional differences in food self-provisioning. They also contribute to a better understanding of a phenomenon whose variability within a rural territory is quite known a little. Even though the suburban and peripheral regions have very comparable natural conditions and opportunities of growing crops (a similar type of estate, nearly the same size of the gardens surveyed), we can observe rather remarkable differences, especially in the extent of the areas being farmed and in the scale of breeding domesticated animals (work demanding activities). Compared to that, only negligible differences were found in growing commodities demanding less work (fruit and tomato growing). The identified differences in attitudes to selfprovisioning in the observed regions (depending on the varied types of population in the regions) allow for analysing the perspectives of particular self-provisioning activities both in South Moravia and the CR on the whole.

Key words: Food self-provisioning, rural household, South Moravia, suburban region, peripheral region

Shrnutí: Česká republika patří $\mathrm{k}$ zemím se silnou tradicí pěstování a výroby potravin v domácnostech. V článku se zaměřujeme výhradně na tradiční a často opomíjený fenomén venkovského samozásobitelství, jež nově $v$ rozdělení příměstí versus periferie analyzujeme na základě dat získaných vlastním šetřením $v$ prostoru jižní Moravy. Oproti dosavadním výzkumům v ČR nebo EU bylo v šetření cíleno pouze na domácnosti s přístupem $k$ půdě, u nichž je možné detailněji zkoumat pěstování širokého spektra komodit, přístupy $k$ pěstování i jeho perspektivy. Výsledky šetření 178 venkovských domácností ve dvou typově odlišných regionech jižní Moravy (příměstském a periferním) v roce 2017 ukazují, v čem se samozásobitelství potravinami $v$ regionech liší. I při téměř stejných přírodních podmínkách a srovnatelných možnostech pěstování v príměstském a periferním regionu (obdobný charakter zástavby, prakticky stejná velikost zahrad domácností v šetření) nacházíme výrazné rozdíly zejména ve výměrách intenzivně obhospodařovaných ploch a rozsahu chování hospodářských zviŕrat (pracovně náročné činnosti). Naopak zanedbatelné rozdíly byly zjištěny $v$ pěstování méně pracných komodit (pěstování ovoce a rajčat). Ze zjištěných rozdílů $v$ přístupech domácností k samozásobení v šetřených regionech, na nichž se silně podílí odlišné složení tamějších populací, Ize usuzovat na perpektivity konkrétních samozásobitelských aktivit nejen na jižní Moravě, ale i v ČR obecně.

Klíčová slova: Samozásobitelství potravinami, venkovská domácnost, jižní Morava, příměstský region, periferní region

\section{Highlights}

- $\quad$ Czech rural food self-provisioning is very widespread and socially diverse.

- Peripheral rural region shows higher orientation towards food self-provisioning.

- Local rural origin of residents affects the extent of food self-provisioning. 
- Households differ in the extent of growing of labour intensive commodities.

\section{Introduction}

The Czech Republic has a strong horticultural tradition and associated activities of food selfprovisioning (FSP) are widely spread in its population. According to the recent representative survey, approximately $38 \%$ of the population in the Czech Republic grow their own fruit or vegetables (Jehlička, Daněk, Vávra 2018). The consumption of many commodities, such as apples, tomatoes, carrots, potatoes, and pears, is commonly covered by the production of Czech households to the amount of more than 40\% (Smith and Jehlička, 2013).

Although FSP is thought to be a rather wide-spread phenomenon, we know quite few details about its present-day nature (e.g., the amount of farmed land, the specifics of growing activities etc.). Rural self-provisioning of Czech households ceased to be monitored by the Czech Statistical Office (CZSO), neither does this topic receive enough attention from researchers and policymakers as shown by Sharashkin (2008) and Taylor, Lovell (2013) in their countries.

The latest available data of the consumption of homemade products in Czech households have been showing a gradual decline in home production of potatoes, vegetable, or livestock, i.e., activities which are traditionally associated with the country. Although, in this respect, the differences between Czech urban and rural areas have still been significant, they have, for many reasons, been lessening.

Our article focuses on the changes in the character of FSP in present-day rural areas, specifically in its various types. Our aim is to compare the level of household production in two rural regions with the same natural conditions for growing crops, but different socioeconomical structure of the population, influenced by their different location in relation to a bigger town. The questions we are attempting to find answers to are for example: are there any differences in households' attitudes to FSP and food self-sufficiency between rural regions of the same natural conditions? If so, what factors play the most important role? Do the differences apply equally to all commonly home-grown commodities? By examining the differences in FSP between suburban and peripheral rural households, we can find out if the decline in rural home food production as shown by the official statistical data is typical of rural households as a whole or if it is more often connected with some household types.

For our comparison, we chose South Moravia - the suburban region of Roketnice lying in the close vicinity of Brno, the second largest city in the CR (the population being significantly influenced by suburbanization), and a peripheral region Babí lom in Hodonín district (despite its location relatively close to Brno, the villages are losing their inhabitants; the population is represented mainly by long-time residents).

Unlike the previous comparative studies on food self-provisioning, we focus merely on the potential own food producers, i.e., land-owning households. This approach allows for a detailed scrutiny of the scope of production-oriented land exploitation, food self-sufficiency of households and the influence of different household compositions on the nature of food selfprovisioning in both the regions. Understanding the role of socioeconomical aspects of rural FSP can generally reveal more about the direction which FSP in the Czech Republic will take in future.

\section{Theroretical background}

Production of one's own food can be considered as part of human nature, as something people have practised collectively ever since they stopped being hunter-gatherers. The extent to which people, or in our case rural households, are involved in taking care of gardens and producing their own food is influenced by many factors of an individual and social nature in addition to the geographical conditions. On the individual level of rural household members, these factors include their interests, hobbies, skills, personal values and opinions, lifestyle, dietary habits, attitudes towards consumption and standard of living and traditions within the family. The family life cycle - age, health and physical capabilities of household members - may also play a large 
role. From the wide range of factors having a pan-social impact, we might mention the social environment, the availability, quality, safety and price of food, local customs and traditions, trends in nutrition and foodstuff consumption. The impact of these factors on the individual or society can then provide a picture of self-provisioning in a particular place at a certain time in history. Cyclical changes in the social importance of taking after gardens has, quite poetically, been summarised by Cílek (2016) stating that taking care of one's garden in hard times is necessary, whereas in good times it is joyful and comforting.

Today, FSP fulfils, in addition to the originally primary economic function, a whole range of purposes, such as environmental, traditional, community and other purposes. FSP plays an important role in various geographical contexts. For example, Jehlička, Daněk (2017) has pointed out the implicit connection between self-provisioning and shortage economy. As a result, a great deal of literature on self-provisioning (home gardening, household food production, grow your own or self-provisioning) has been focusing on poor regions, ethnic minorities or social groups where self-provisioning constitutes an essential part of household economy (Jensen et al. 1995, Campbell et al. 1993, Mingione 1991, Pahl, Wallace 1985). The research into this phenomenon in countries of the "global north" is insufficient; only in recent years, studies filling this gap have appeared (Church et al. 2015, Goodman et al. 2012, Kneafsey et al. 2008, McClintock 2014, McEntee 2010, Schupp et al. 2016, Schupp, Sharp 2012).

According to the comparative study of Alber, Kohler (2008), less than 10\% of the population of Western European countries is engaged in self-provisioning, whereas in post-communist countries, it is still around 35-60 \% - namely $38 \%$ in the Czech Republic in 2015, 36\% in Hungary in 2013 or 54\% in Poland in 2011 (Jehlička, Daněk 2017, Balázs 2016, Smith and Jehlička 2013). Needless to say, more frequent production of one's own food can be expected in the countryside - in many European (not only Eastern) countries, it is more than 50\% (Vávra, 2017). Also in the countries of Eastern bloc, where FSP is spread more widely, the authors' focus has primarily been put more on its economic aspects (Acheson 2007, Torsello 2005, Czegledy 2002, Dvořáková- Janů 1999, Skalník 1993, Sik 1992). But lately, the focus has been turning more to ecological, social, and individual motives and features of home food production (Pungas 2019, Nenashev, D. 2018, Jehlička, Daněk 2017, Hormel, 2016, Jehlička, Kostelecký, Smith 2013, Jehlička, Smith 2011, Zavisca 2013).

In connection with the analysis of interregional differences in FSP, studied by Sovová, Veen (2020), Nenashev (2018), Vávra et al. (2017), Vávra (2013), Vávra et al. (2018), it is necessary to point out the works of Jehlička (Jehlička, Smith 2011, Jehlička, Kostelecký, Smith 2013, Jehlička, Daněk 2017, Smith, Jehlička 2007). These works decidedly stand against the tendencies in European comparisons, which claim that it is being poor or somehow economically disadvantaged (compared to Western Europe) that accounts for the relatively high level of food self-provisioning in the Czech Republic and other post-communist countries (as presented by Alber, Kohler (2008)). According to Jehlička, Daněk (2017), FSP in the postcommunist countries is necessary to be viewed as an idiosyncratic cultural phenomenon that has many non-economic functions (for those engaged in it).

When we study the motivation for FSP, it is particularly the household's economy that has till now remained the most disputed reason for engaging in food self-provisioning. After housing, food represents the most significant part of a household's budget (in the CR, currently around $20 \%$, in 1989 , it represented around $1 / 3$ of a family budget). The prices for good quality food products have been rising, which make us conclude that FSP allows households to cut down on expenditure. On the other hand, the investment of time and money into producing one's own food can exceed the volume of resources which would be needed to buy it on the market (Ulčák 2006: 298). While a number of authors consider the economic motivation as basic (Alber, Kohler 2008, DvořákováJanů 1999, Campbell et al. 1993, Mingione 1991), other authors do not agree (Felt, Sinclair 1992; Omohundro 1995). Their beliefs may be supported by a research into the reasons for selfprovisioning in Czech households conducted by the CZSO - for $61 \%$ of the respondents, selfprovisioning was a hobby, and only around one quarter of households did it for economic reasons (CZSO 2007). Also, Teitelbaum, Beckley (2006), leading a research into FSP in Canada (2006), or Sharashkin in Russia (2008), claim that the groups with the lowest income displayed the lowest level of self-provisioning aktivity. This, however, is often influenced by poorer access to land. 
Together with the economic benefit of FSP for households, there have also been debates about its significance in the environment. Greenness of self-provisioning can be perceived from the level of a person's care for the environment when self-provisioning is practised in the spirit of sustainable development principles (maintaining rural or urban gardens or allotments, fields) and in the production of high-quality, safe local foods (i.e. foods produced with minimal chemicals and consumed at the place of production, without a need for long-distance transportation to the end consumer). According to Škantová (2009), the emphasis on the quality of home-grown food is associated with the increasing awareness of health risks connected with the production of commercial food (foods treated with chemicals or hormones).

We can see a similar tendency in evaluating the social importance of FSP and its environmental aspects. Both are evaluated differently in different geographical contexts. We tend to speak of ecological aspects of FSP more often in urban and suburban contexts and in Western European countries than in rural areas and in post-soviet countries. FSP is more widely spread there and is primarily connected with economical aspects (Goodman et al. 2012, De Hoop and Jehlička, 2017, Pungas, 2019). For example, while we can clearly see the environmental benefits of urban allotments in respect to $\mathrm{CO}_{2}$ absorption, diminishing the urban heat island effect, retaining rainwater, decreasing noise and dust pollution, supporting biodiversity, creating refuges for organisms (Okvat and Zautra 2011), the environmental benefits of FSP in the rural context are scrutinised less often. However, even here, we can bring about a range of questions concerning the present-day changes in the life in the country, where the area of productive economic gardens is gradually being reduced, vegetable beds are being replaced by swimming pools, chemically maintained lawns and other features inspired by urban lifestyle (Klvač, Ulčák, 2008).

Besides the above mentioned economic and environmental benefits, certain authors (Gibas 2013, Keller, Cílek 2016, Librová 2003, Novák 2013) also perceive FSP as a welcome alternative to the market economy and the way of life associated with it, or as an activity benefitting the formation of healthy society. Positive impacts on the health or the lifestyle of individuals have been documented by e.g., Freeman et al., 2012, McClintock 2010, Garnett 2000 and Teitelbaum, Beckley 2006. These examples paradoxically show self-provisioning activities to be actually consumer rather than production activities. Among these activities, FSP is more a way of spending free time than working.

In conclusion, we can clearly state that the significance of cities for population (e.g., in the CR, $73 \%$ of population lives in cities), hand in hand with current popularity of a few other topics (e.g., sustainability in food consumption, environmental and lifestyle benefits, the role of FSP in community development), accounts for the relatively bigger amount of technical literature on urban and peri-urban gardening (Guitart et al. 2012, Draper, Freedman, 2010, Klvač, 2013, Taylor, Lovell, 2013, Gibas, Novák 2013, Sovová, Krylová 2019, Pungas 2019). The rural FSP, on the other hand, is somehow neglected. The view of Škantová (2009), who claims that FSP has become a more independent subject matter of research only in the time of its decline, does not apply to FSP in Czech rural areas.

\section{Data and methods}

In the article, we draw upon two data sets. We work with the data from the Household Budget Survey of the CZSO on Czech rural FSP (see Results 1) and with the data obtained by a field survey conducted by the Institute of Agricultural Economics and Information (IAEI Survey, 2017) in two South-Moravian rural regions from August to October 2017 (see Results 2).

Relying on the official statistical data from the Household Budget Survey, we briefly present the importance and long-term development of Czech households' self-sufficiency in food production. We use in-kind personal consumption data to show the trends in consumption of their own food products and the existing differences in the extent of food self-sufficiency in rural areas and in large cities.

The aim of the IAEI questionnaire study was to examine the extent of rural FSP among households in compared regions (suburban and peripheral) more thoroughly and subsequently investigate the issues that have remained marginal for researchers so far. The extent of FSP in 
the regions was examined on the basis of questionnaires gained from 100 respondents in the suburban region and 78 in the peripheral one (see Table 3). The interviewers from the IAEI physically distributed the forms to residents over the age of 18 via randomly addressing house dwellers with access to land only (they provided the residents with the instructions, conducted a face to face interview for getting the hard-copy version of the questionnare or gave the link of the questionnare to those interviewees who preferred the online version).

By focusing exclusively on land owners, our field study very much differs from the previous surveys of FSP, which provided a better overview of food self-sufficiency on the state level (Vávra et al. 2017, Jehlička, Daněk 2017), but did not allow for the phenomenon to be examined in more detail. In addition, our approach allowed us to analyze the collected data on the level of whole rural households, instead of merely the respondents, as FSP is a phenomenon involving more family members. Categorizing the number of 178 rural households according to attributes such as age, education, social status or local origin and their subsequent comparison of different types of households, it provided us with a better understanding of the factors standing behind the identified inter-regional differences in FSP.

As previous papers studied the general influence of age and social status on the extent of FSP (Vávra et. al. 2017, Jehlička, Daněk 2017), we are newly focusing mainly on the factor of the local rural origin of households. In the text, we describe the FSP activities of the households of longtime residents (people who have been living in the region since childhood - both the partners are of local rural region) and the households of newcomers (neither of the partners was of the local rural origin).

The basic indicators of surveyed rural gardens and allotments, and the garden classification, are given in Table 1. Different types of rural gardens in the regions are determined on respondents estimates of their functional parts (i.e., the shares of the total garden area). In the article, we distinguished between productive gardens (with a predominance of food production), decorative gardens, mostly unmaintained gardens (all specified in Table 1) and other gardens (their functional parts were not specified, or each of the functional parts was practically the same in terms of area).

Tab 1. Basic indicators on rural gardens and allotments in the IAEI Survey 2017.

\begin{tabular}{||l|l||}
\hline Indicator & Specification of a garden indicator \\
\hline Garden area $\left(\mathrm{m}^{2}\right)$ & $\begin{array}{l}\text { Area of land near the house according to the estimate of } \\
\text { respondents. Built-up areas were not included. }\end{array}$ \\
\hline Allotment area $\left(\mathrm{m}^{2}\right)$ & $\begin{array}{l}\text { Area of farmed land located in the vicinity of a house (very often } \\
\text { situated at the edge of the village) according to the estimate of } \\
\text { respondents. Areas of garden plots in other regions are not } \\
\text { included. }\end{array}$ \\
\hline $\begin{array}{l}\text { Intensively farmed area of garden } \\
\left.\text { and allotment (m }{ }^{2}\right)\end{array}$ & $\begin{array}{l}\text { Areas of beds or intensively cultivated areas of gardens and } \\
\text { allotments (ploughed plots) }\end{array}$ \\
\hline $\begin{array}{l}\text { Position of the house (garden) in the } \\
\text { village }\end{array}$ & $\begin{array}{l}\text { Rural garden types } \\
\text { the village was not specified. }\end{array}$ \\
\hline $\begin{array}{l}\text { Share of garden area intended for } \\
\text { food production (\%) }\end{array}$ & $\begin{array}{l}\text { Productive gardens are gardens in which the largest relative area } \\
\text { (\%) comprises areas used for food production (i.e. beds, orchards, } \\
\text { livestock areas, greenhouse areas, areas of fodder production) }\end{array}$ \\
\hline $\begin{array}{l}\text { Share of garden area intended for } \\
\text { recreation and relaxation (\%) }\end{array}$ & $\begin{array}{l}\text { Decorative gardens are gardens in which the largest relative area } \\
\text { (\%) is taken up by areas of decorative vegetation or residential } \\
\text { and relaxation areas (i.e. lawn, decorative trees and bushes, } \\
\text { seating, play areas, swimming pool). }\end{array}$ \\
\hline $\begin{array}{l}\text { Share of unmaintained part of the } \\
\text { garden (\%) }\end{array}$ & $\begin{array}{l}\text { Mostly unmaintained gardens are gardens whose larger area is } \\
\text { unused. }\end{array}$ \\
\hline
\end{tabular}




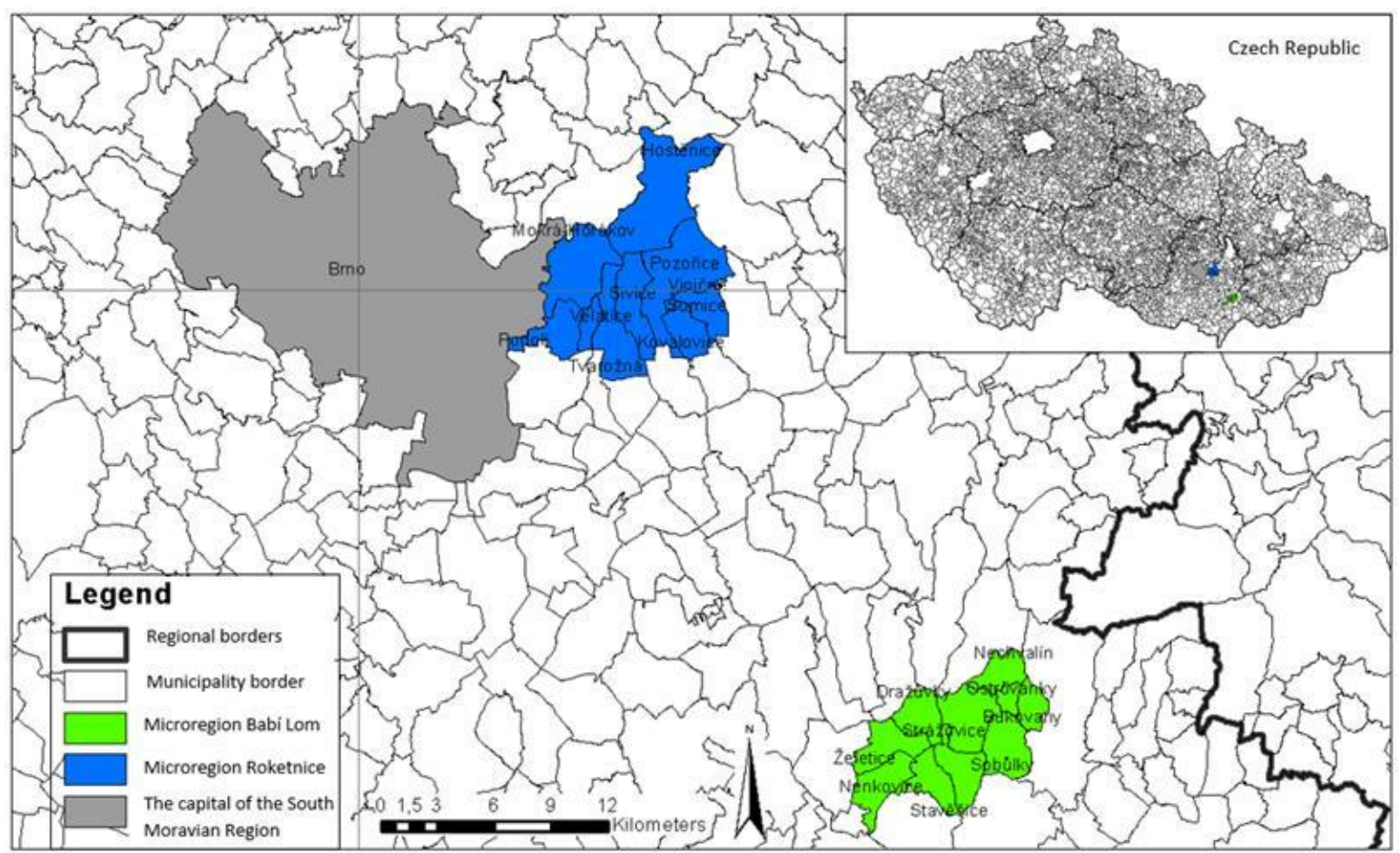

Fig 1. Position of selected rural regions in South Moravia and in the Czech Republic.

Notes: The Roketnice microregion included the municipalities of Hostěnice, Kovalovice, Mokrá-Horákov (the municipality left in 2018), Podolí, Pozořice, Sivice, Tvarožná, Velatice and Viničné Šumice. The microregion Babí lom included the municipalities of Bukovany, Dražůvky, Nechvalín, Nenkovice (the municipality left in 2017), Ostrovánky, Sobůlky, Stavěšice, Strážovice, Věteřov, Želetice.

Self-sufficiency of rural households in covering their annual or seasonal consumption of food by their own production was determined for a total of 21 plant commodities. In this paper, we present home production of five commonly grown commodities with good storability in an unprocessed state (root vegetables, onion, garlic, potatoes and zuchini) and five commonly grown vegetables that can not be expected to be stored fresh for most of the year (tomatoes, cucumbers, peppers, leafy and cruciferous vegetables). Finally, the IAEI Survey focused on the scope of home processing and the respondents' attitudes towards FSP.

When selecting rural regions for comparative analysis, we used the typology of the rural area of the Czech Republic by Perlín, Kučera, Kučerová (2010), dividing the contryside of the Czech Republic into eight categories according to the potential for development. The suburban region was represented by the microregion Roketnice in district Brno-rural (immediate hinterlands of city of Brno), it is classified as a developing rural area. To investigate the peripheral region, the microregion Babí lom in the district of Hodonín was chosen. In the Perlin's typology, its municipalities belong under the category of Moravian peripheries. The paper of Stonawska, Vaishar (2018) on the differentiation and typology of the Moravian countryside characterizes the microregion as an example of deficit countryside (unfavourable demographic characteristics are manifested in the long-term depopulation and out-migration, progressive population ageing and common negative attitudes of residents towards business and cultural development in the region).

The position of regions in South Moravia is illustrated in Figure 1. South Moravia was chosen as an area with good natural conditions for agriculture and a long tradition of domestic food production.

Both regions are characterised by a similar landscape and climate (both in a warm climatic area, average annual temperature $8-9^{\circ} \mathrm{C}$, in recent years around $10^{\circ} \mathrm{C}$ ). They are farmed relatively intensively (more than $80 \%$ of the farmland is arable). Most of the municipalities in both regions are 200 to 300 metres above sea level. In spite of the comparable and overall favourable natural conditions for farming in both regions, they differ in terms of employment in the agricultural sector. 
The proportion of people employed in farming, forestry and fisheries in the Babí lom microregion was above average (3.5\% compared to $2.7 \%$ for the whole Czech Republic), but it does not reach the level of those employed in rural areas (6.5\% according to census 2011). Conversely, agricultural employment in the suburban microregion of Roketnice is below the Czech Republic average $(2.5 \%)$.

A difference between the regions can be seen mainly in the population size of municipalities, population density (see Table 2), demographic structure of inhabitants and unemployment and educational indicators. Like many municipalities near a larger city, the municipalities of the Roketnice microregion are characterised by population growth (mainly due to suburbanisation). Due mainly to immigration to the microregion, the category of persons up to 14 years of age slightly exceeds that of those 65 and older $(17.8 \%$ to $13.4 \%$ (CZSO, 2017)). Unemployment in the microregion is significantly below the Czech Republic average, the availability of work being closely linked to the city of Brno. The territory is characterised by a dense public transport network, good traffic accessibility to the centre and good technical infrastructure and public services. By contrast, the municipalities of the peripheral microregion in the Hodonín district are seeing a slight decline in population and are ageing from a demographic aspect. In the population structure of the microregion's municipalities, people aged over 65 significantly outnumbered those younger than 14 (20.7\% compared to $13.4 \%$ in 2017$)$. The increasing number of uninhabited houses or houses inhabited by only one person corresponds to the long-term negative population development. The Hodonín district has one of the highest proportions of local residents in the Czech Republic. Unemployment above and education below the Czech Republic's averages do not contribute to the economic development of the territory $-24.3 \%$ of population of Babí lom had only primary education (CZSO, 2011), average proportion of unemployed persons was $7.4 \%$ (compared to $3.6 \%$ in suburban Roketnice (MLSA, 2017)).

Tab 2. Basic socio-demographic indicators of the municipalities of suburban and peripheral microregions in 2016. Sources: Small lexicon of municipalities 2015, 2016, CZSO 2016, 2017. Author's own calculations

\begin{tabular}{|c|c|c|}
\hline Indicator & $\begin{array}{c}\text { Microregion } \\
\text { Roketnice } \\
\text { (suburban) }\end{array}$ & $\begin{array}{c}\text { Microregion Babí } \\
\text { lom }^{1} \\
\text { (peripheral) }\end{array}$ \\
\hline Area $\left(\mathrm{km}^{2}\right)$ & 86.3 & 53.1 \\
\hline Population & 12489 & 4824 \\
\hline Number of rural municipalities & 9 & 10 \\
\hline Population density (inhabitants $/ \mathrm{km}^{2}$ ) & 144.7 & 90.8 \\
\hline Average population size of municipality (inhabitants) & 1387.7 & 482.4 \\
\hline
\end{tabular}

Notes: ${ }^{1}$ Data relating to the Babi lom microregion applies only to the rural municipalities of the microregion, i.e., without the town of Kyjov.

\section{Results 1. Food Self-Provisioning in the Czech Republic - comparison of rural and urban areas}

From an analysis of official data sources of CZSO, it is evident that for many commodities, household production in the Czech Republic reaches a significant, and in many cases major, proportion compared to the farming sector of the Czech Republic. Crops whose proportion of cultivation area or household production is higher than in the agricultural sector include cucumbers, gherkins, strawberries, kohlrabi, tomatoes and garlic. Czech households also have large numbers of most of the grown fruit trees and bushes (household production of cherries, peaches, apricots and plums is significant). The production of rabbit meat is also concentrated in home operations, which represents $84.5 \%$ of the total production of rabbit meat in the Czech Republic. By contrast, the proportion of pork production in the country is $3.8 \%$ and poultry $1.8 \%$ of the total production of these commodities. Households contributed $36.9 \%$ to overall egg production in the Czech Republic (CZSO 2006). 
The Household Budget Survey shows the long-term and significant effect of self-provisioning of Czech households with their own products - even after nearly 30 years since 1989, the proportion of in-kind consumption of certain commodities remains relatively significant. Figure 2 shows that the proportion of in-kind consumption of some commodities in the first half of the 1990s grew slightly, although since the mid-1990s, the significance of self-provisioning with people's own products gradually dropped. The greatest drop has been in the home production of meat (primarily pork) and vegetables.

Production of meat in households as a proportion of overall meat consumption reached its highest level in 1994 (approximately 18\%, and in the case of pork, approximately 30\%). By 2015, the level of meat self-sufficiency in Czech households had dropped below 6\%. The figures for poultry kept at home for meat experienced a similar development ( $20 \%$ of consumption from people's own sources in 1991, today around 4\%). Rabbit keeping is more stable, but even in this case, home production is half of what it was in the period 1993-1998 (no precise data is available on the overall consumption of rabbit meat in households). Out of animal production in households, egg production has maintained its position more than any other item.

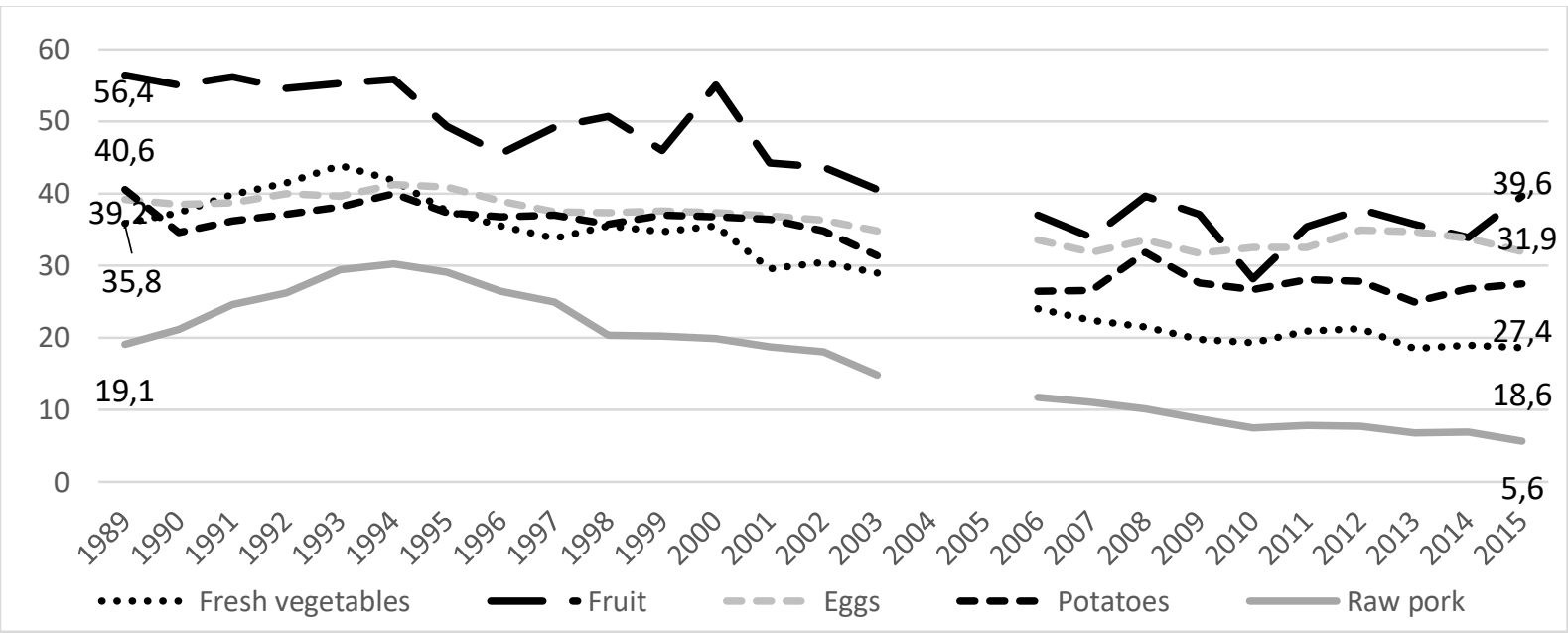

Fig 2. Development of in-kind consumption out of total consumption of selected commodities in the Czech Republic after 1989 (\%). Data for 2004-2005 and after 2015 is not available. Source: Household Budget Survey, Czech Statistical Office 2004, 2008-2017

After 2006 (older data broken down according to municipality size is not available), we were able to observe the development in the proportion of in-kind consumption in rural municipalities (municipalities up to 2000 population) compared with larger towns (with 50,000 or more population). Figures 3 and 4 show that to this day, a very high proportion of in-kind consumption of eggs remains (exceeding $50 \%$ in the countryside), as well as temperate zone fruit (the most frequent annual fluctuations reflect the weather conditions of specific years) and potatoes (around $40 \%$ ). Self-sufficiency in animal products (pork, lard and bacon) for rural households is near the level of household self-sufficiency in larger towns. With the exception of temperate zone fruit, self-sufficiency in Czech urban households with their own commodities is below 20\%, but the drop in the scope of self-provisioning activities is less than in the countryside. 


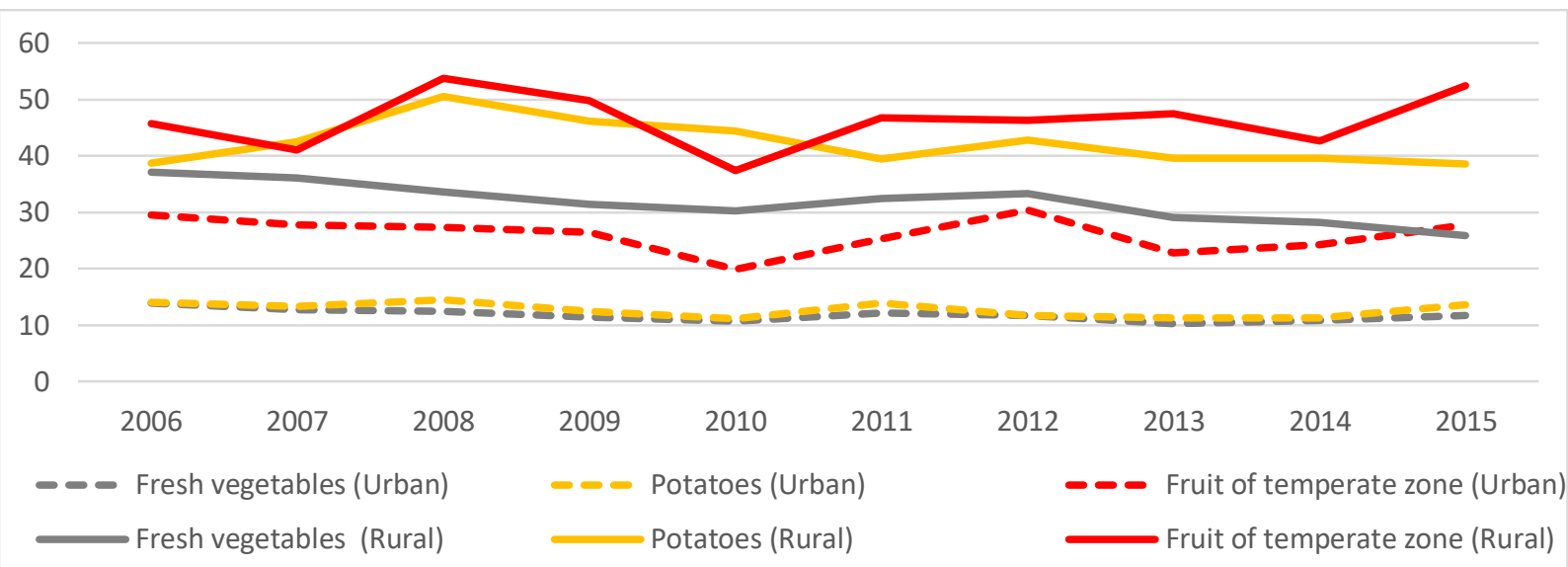

Fig 3. Proportion of in-kind consumption of selected plant products in rural and urban households in the Czech Republic in the years 2006-2015 (\%). Source: Household Budget Survey, Czech Statistical Office 2008-2017

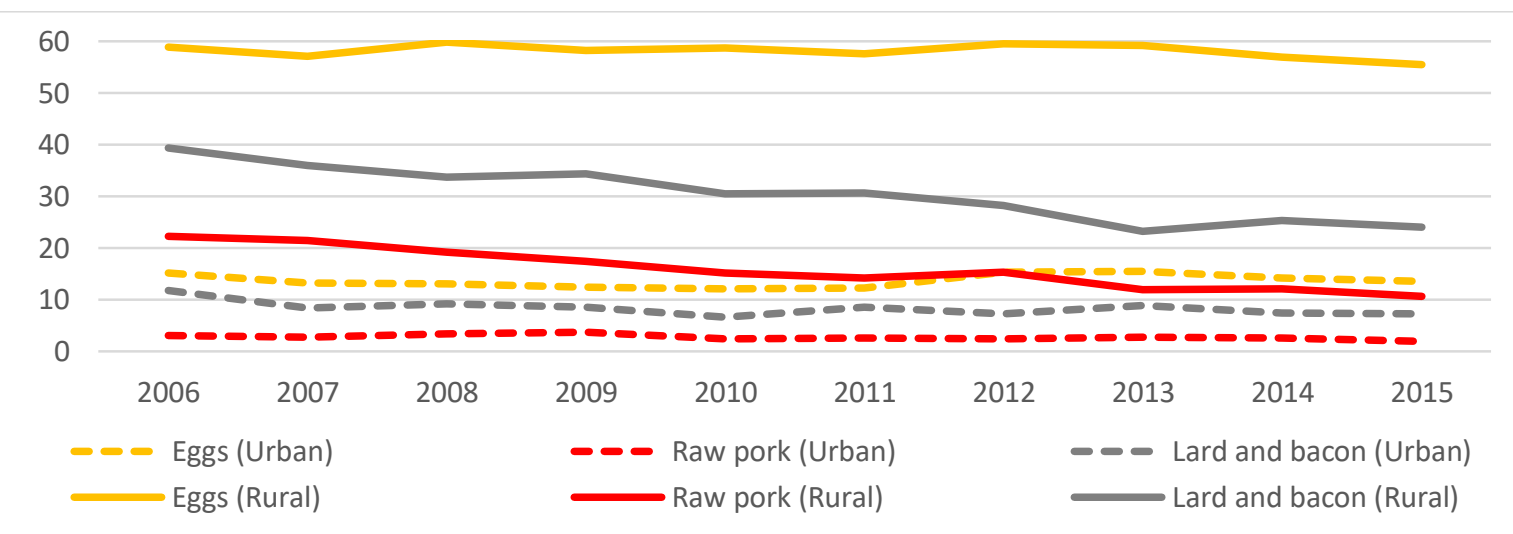

Fig 4. Proportion of in-kind consumption of selected animal commodities in rural and urban households in the Czech Republic in the years 2006-2015 (\%). Source: Household Budget Survey, Czech Statistical Office 2008-2017

\section{Results 2. Rural Food Self-Provisioning in South Moravia - comparison of suburban and peripheral regions}

The analysis of self-provisioning activities and differences between the regions is based on an analysis of experience with food self-provisioning from 178 respondents ( 100 households from the suburban region, 78 from the peripheral). Basic data on respondents and types of their gardens is shown in Table 3.

One limitation in comparing self-provisioning in the regions is the fact that a greater difference exists between the analysed samples of rural households in both regions than according to the monitored indicators between their populations ${ }^{2}$ (as you can see in Table 3 , a very low number of suburban households had persons over the age of 60 , suburban households had a higher proportion of university graduates, etc.). We attempt to take this into account in the individual evaluated differences between rural microregions despite surveys such as Vávra et al. (2017) and Jehlička, Daněk (2017) generally not confirming the fundamental significance of education and economic status of respondents to the level of household self-provisioning in the Czech Republic and other countries. The conclusions from surveys by Vávra et al. (2017) and Jehlička and Daněk (2017) on significance of age on FSP activities differ. On the other hand, the great benefit in comparing household food self-sufficiency in both regions is the survey ascertaining the comparable size structure of respondents' gardens and the practically identical proportion of houses in old developments (more than $70 \%$ in both regions). The different surveyed levels of FSP in the regions are thus not influenced by the differences in garden area where it is possible to grow food.

\footnotetext{
${ }^{2}$ Data on the current social structure of house dwellers is not available.
} 
Tab 3. Basic data about respondents (rural households) and their land in the IAEI Survey 2017. Source: IAEI Survey 2017

\begin{tabular}{|c|c|c|c|}
\hline Rural households & $\begin{array}{c}\text { Microregion } \\
\text { Roketnice } \\
\text { (suburban) }\end{array}$ & $\begin{array}{c}\text { Microregion } \\
\text { Babí lom } \\
\text { (peripheral) }\end{array}$ & Total \\
\hline Number of respondents (rural households) & 100 & 78 & 178.0 \\
\hline Persons up to the age of $40(\%)$ & 56.0 & 24.3 & 42.1 \\
\hline Persons aged $41-60(\%)$ & 38.0 & 46.2 & 41.6 \\
\hline Persons aged 61 and older (\%) & 6.0 & 29.5 & 16.3 \\
\hline Households of long-time residents (\%) & 31.0 & 65.4 & 46.1 \\
\hline Households of newcomers (\%) & 36.0 & 11.5 & 25.2 \\
\hline Households of people of mixed origin (\%) & 33.0 & 23.1 & 28.7 \\
\hline Households of people with lower education (\%) & 8.0 & 24.4 & 15.2 \\
\hline Households of people with higher education (\%) & 76.0 & 51.3 & 65.2 \\
\hline Households of employed people (\%) & 66.0 & 51.3 & 59.6 \\
\hline Households of pensioners (\%) & 5.0 & 29.5 & 15.8 \\
\hline \multicolumn{4}{|l|}{ Rural gardens and allotments } \\
\hline Share of houses/gardens in old developments (\%) & 73.0 & 74.4 & 73.3 \\
\hline Average size of garden at house $\left(\mathrm{m}^{2}\right)$ & 939.6 & 866.5 & 907.4 \\
\hline Average size of allotment $\left(\mathrm{m}^{2}\right)$ & 1622.2 & 2315.9 & 2262.0 \\
\hline Respondents using allotments (\%) & 23.0 & 37.1 & 29.2 \\
\hline Average share of productive part of garden (\%) & 36.7 & 51.8 & 43.3 \\
\hline Average share of decorative part of garden (\%) & 44.4 & 35.3 & 40.4 \\
\hline Households with productive gardens (\%) & 28.3 & 48.7 & 37.7 \\
\hline Households with decorative gardens (\%) & 43.4 & 30.3 & 37.1 \\
\hline Households with unmaintained gardens (\%) & 15.2 & 7.9 & 12.0 \\
\hline $\begin{array}{l}\text { Average share of intensively cultivated areas } \\
\text { of gardens and allotments }\left(\mathrm{m}^{2}\right)\end{array}$ & 302.3 & 857.7 & 548.2 \\
\hline
\end{tabular}

Although the size structure of gardens in both microregions does not differ much (Figure 5), the character of rural gardens differs greatly (see Table 3). The peripheral microregion had a higher proportion of gardens that we describe as productive $-48.7 \%$ compared with $28.3 \%$ in Roketnice. According to IAEI Survey results, the productive garden, where the largest area is set aside for food production, is the most common type of garden in the peripheral microregion. In the suburban microregion of Roketnice, most gardens were decorative or for relaxation $(43.4 \%$ of households), where the largest area was taken up by a lawn, decorative trees and bushes, seating, play areas, etc. Unmaintained gardens with the predominance of unused land were more common in the suburban microregion of Roketnice.

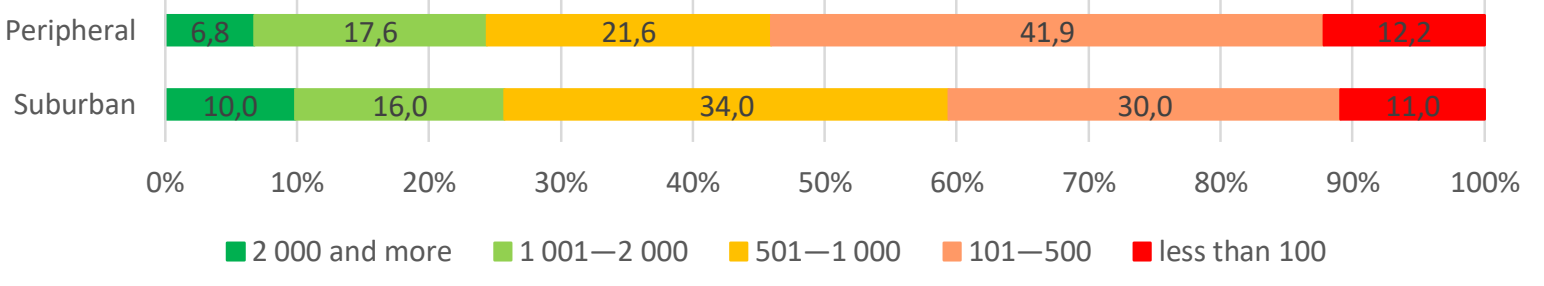

Fig 5. Rural households according to the garden area $\left(\mathrm{m}^{2}\right)$. Source: IAEI Survey 2017

The more striking orientation towards productive use of gardens in the peripheral region is also shown by the higher average proportion of garden areas intended for production, the higher proportion of households using their gardens exclusively for food production $(10.5 \%$ compared 
with $2 \%$ ) and primarily the larger area of total intensively food-producing land (cultivated garden, including allotments), as shown in Figure 6.

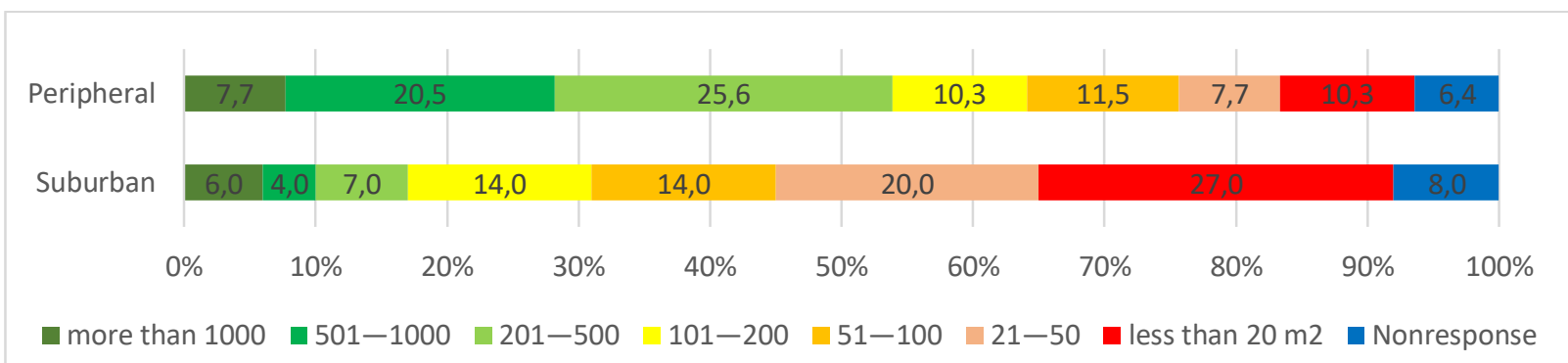

Fig 6. Rural households according to the area of intensively farmed garden and allotment areas $\left(\mathrm{m}^{2}\right)$. Source: IAEI Survey 2017

The results of the IAEI Survey show that for most of rural households in both regions, the garden at a house is the main source of food self-provisioning. A minority of inhabitants in both regions used an allotment (29.2\%). A larger average size of allotment was found in the peripheral microregion (but this was significantly influenced by a few larger allotments with areas greater than $10000 \mathrm{~m}^{2}$ ). In the suburban region, they most frequently served to produce fruit, while in the peripheral region, potatoes. In both regions, the households of pensioners and long-time residents were more likely in relative terms to grow produce on allotments.

The vast majority of rural households in both regions used their land in some way for food production, and only around $6 \%$ of households in both territories did not use it for growing and animal husbandry. According to respondents opinions, the size of gardens in either region is not a limiting factor for FSP, and only less than 14\% of respondents of both regions considered their garden to be too small for growing and animal husbandry (typically, it concerned houses with garden area up to $100 \mathrm{~m}^{2}$ ).

More than $92 \%$ of households in both regions grew vegetables, only less than $5 \%$ of family gardens had no fruit trees (frequently, smaller gardens of pensioners in old developments). Both regions showed a very similar number of fruit trees per $100 \mathrm{~m}^{2}$ of garden (around 1.3), and the average rural households had 11 fruit trees in their gardens at the house. Only a small number of rural households regularly consumed only purchased vegetables - depending on the specific commodity, as a rule $5-30 \%$.

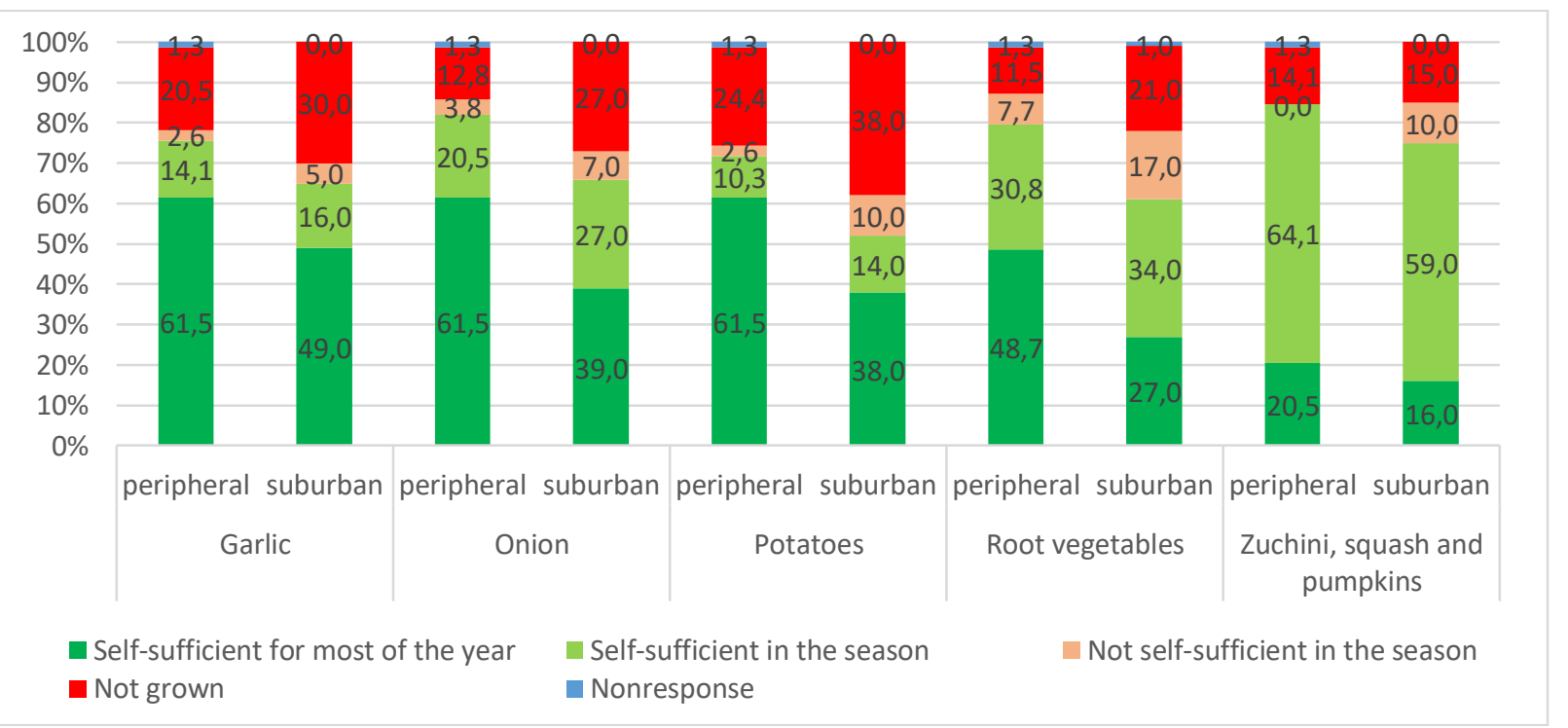

Fig 7. Peripheral and suburban households and level of coverage of annual consumption by their own production storable vegetables (\%). Source: IAEI Survey 2017 
The results of the IAEI Survey show that households in the peripheral microregion grow most commodities relatively frequently, growing them more often in an amount which allows (depending on the possibilities for storage in fresh state) the consumption of their own food for most of the year. The consumption of only home-grown products (i.e., full self-sufficiency, but including shared production between family and friends) was observed relatively more frequently in the peripheral region - at least half of the households do not buy (consume only home-grown) courgettes and marrows, onions, potatoes, strawberries, raspberries and blackberries, blackcurrants, cherries, plums, apricots and walnuts. In the suburban microregion, at least half of rural households were self-sufficient only in blackcurrants, raspberries, blackberries and cherries. More than $60 \%$ of households in the peripheral region could manage a large part of the year with their own crops of potatoes, garlic and onions (see Figure 7). In the suburban region of Roketnice, a higher proportion of households did not cover their needs even seasonally. Significant interregional differences were found in the relatively more frequent self-sufficiency of households in the peripheral region in commodities that can be stored easily - onions, root vegetables, potatoes and garlic. Households in the peripheral region showed greater self-sufficiency in commodities with limited storage time in a fresh state, such as peppers and cucumbers. Practically no difference in both regions was seen in household self-sufficiency for tomatoes, leafy vegetables and cruciferous vegetables (Figure 8) and pulses.

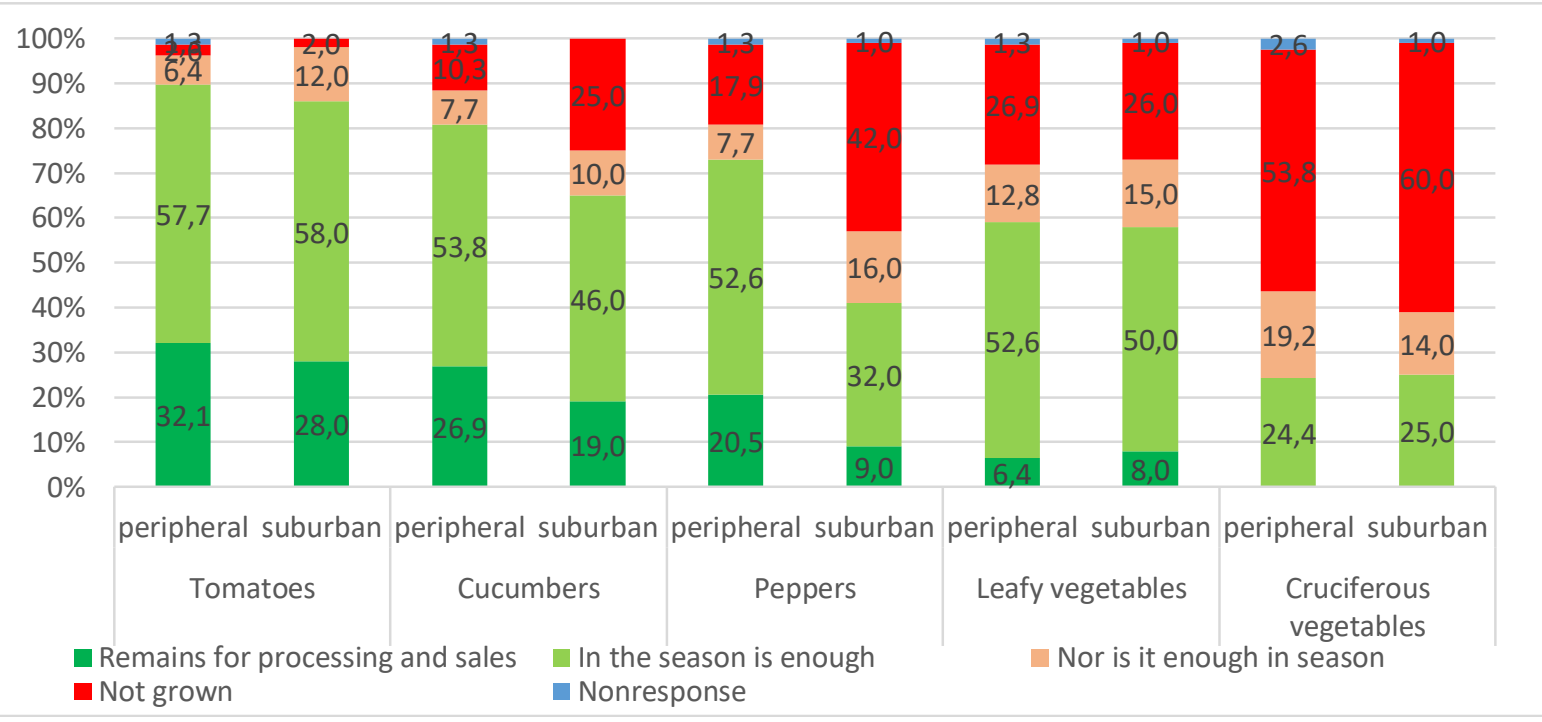

Fig 8. Peripheral and suburban households and level of coverage of seasonal consumption by their own production non-storable vegetables (\%). Source: IAEI Survey 2017

In view of the overall lower household self-sufficiency in the suburban region for most commodities, the finding that suburban households more frequently have increased production of their own food in recent decades can be considered natural (younger families with relatively higher total food consumption and with smaller areas of intensively farmed land).

The lowest expansion of people's own production applied to growing potatoes and grapes (vulnerability of potatoes to drought plays a crucial role in both regions). The households of both regions also had a very different approach to growing herbs - in the last ten years, it has increased to more than $60 \%$ of households in the suburban region, but only one-quarter of households in the peripheral region.

An evident and more striking difference can be observed in animal husbandry and growing animal feed. A minority of respondents in both regions confirmed that they kept domesticated animals. A relatively larger number of households in the peripheral microregion keep them (more than $38 \%$ of households in a peripheral region keep laying hens compared with a somewhat less than $20 \%$ in a suburban region), rabbits (26\% compared with $11 \%)$ and pigs (6\% compared with $2 \%)$. Bees, sheep, goats and turkeys are kept in the regions without significant differences in numbers (up to $5 \%$ ). The attitudes of respondents towards gardening and keeping domesticated animals in both rural microregions are given in Figure 9. 


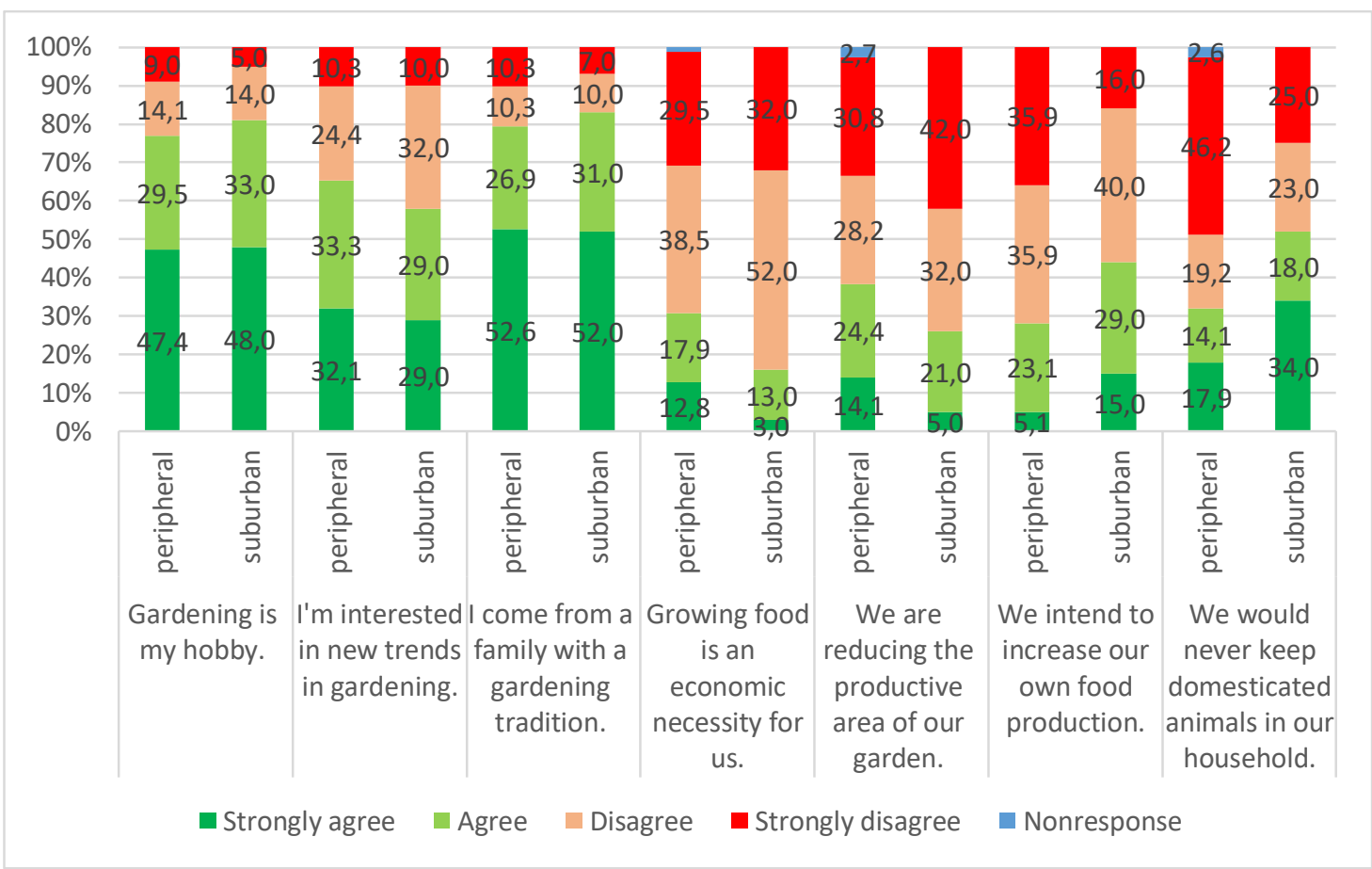

Fig 9. Attitudes of respondents towards gardening in different types of rural regions (\%). Source: IAEI Survey 2017

Figure 10 shows the ascertained frequency of home production of selected food products. The most common type of food processing is bottling fruit or vegetables (more than $90 \%$ in the peripheral region and more than $80 \%$ of households in the suburban region).

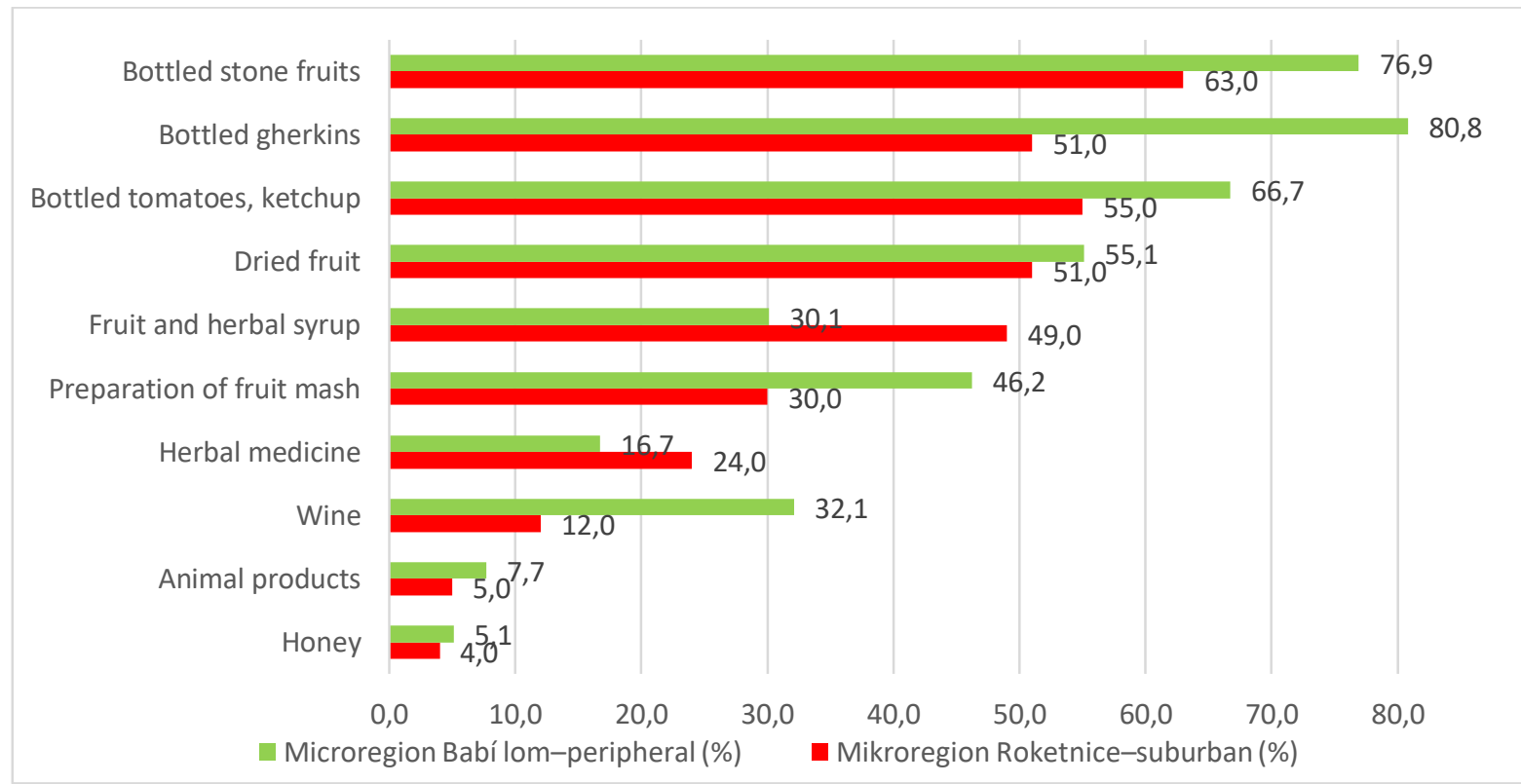

Fig 10. Food production of rural households according to processed commodity (\%). Source: IAEI Survey 2017

When comparing the rural regions, it may seem that a higher orientation towards FSP in the peripheral region (more frequent use of allotments for food production, larger areas of land intensively cultivated, higher frequency of keeping domesticated animals and growing some commodities etc.) is primarily caused by a higher proportion of older people (mostly pensioners) in the sample. Households of pensioners cultivated larger areas of land intensively in both regions, their households are generally smaller and thus more often sufficient in most of the commodities. Producing commodities such as rabbit meat, eggs, potatoes, wine, fruit mash or bottled gherkins is associated with their households in both regions more often. Our results 
prove that more intensive growing of food and keeping domesticated animals in the peripheral region can be seen in all household types regardless of age. However, the extent of home production is strikingly higher in households of people aged 41-60, who contrary to households of pensioners, farmed even larger plots of land (typically allotments etc.).

Another significant factor (besides age) affecting the inter-regional differences in FSP is the local rural origin of residents (differences in attitudes towards gardening are given in Figure 11). Longtime residents in both regions (with the average age of respondents of 50.8 years, more represented in the peripheral region as shown in Table 3) were more often sufficient in most of the surveyed commodities throughout the year compared to families of newcomers. This is primarily influenced by larger total area of land they cultivated (on average, 34\% of them kept and farmed allotments, almost $50 \%$ of the garden area was used for food production), larger areas being farmed intensively (around $1 / 3$ of these households ploughed areas over $500 \mathrm{~m}^{2}$ ), the higher frequency of using agrochemicals, better storage capacities (households in old developments are more often equipped by cellars enabling storing crops). The fact that these families had fewer members also plays an important role. What distinguishes them from the other types of rural households, is their mostly positive attitude to keeping domesticated animals (often laying hens and rabbits), which enables them to improve the soil with manure and thus raise the harvest. The only surveyed commodity which was grown and processed less frequently in these types of families is herbs (typically grown by households of people under 40).

The households of newcomers (often new in-migrants from towns with the average age of respondents of 44.1 year and with a fundamentally higher proportion in the suburban region) displayed a very positive relationship with gardening. They also claimed a strong tradition of gardening within the family. Although their gardens were even larger (on average $1044 \mathrm{~m}^{2}$ contrary to long-time residents with the average garden area of $840 \mathrm{~m}^{2}$ ), they cultivated relatively smaller plots intensively and thus they were less self-sufficient in most of the surveyed commodities. And even though $60 \%$ of them were interested in new gardening trends and more than $50 \%$ of them wished to grow more food in the future, their intentions of increasing food production were hardly ever related to farming on allotments, keeping domesticated animals, growing potatoes and root vegetables, or growing grapes and producing wine. New residents in both regions saw gardening more often as a leisure activity and considered FSP as a loss from an economic perspective (only $6 \%$ saw it as a financial boost to the family budget).

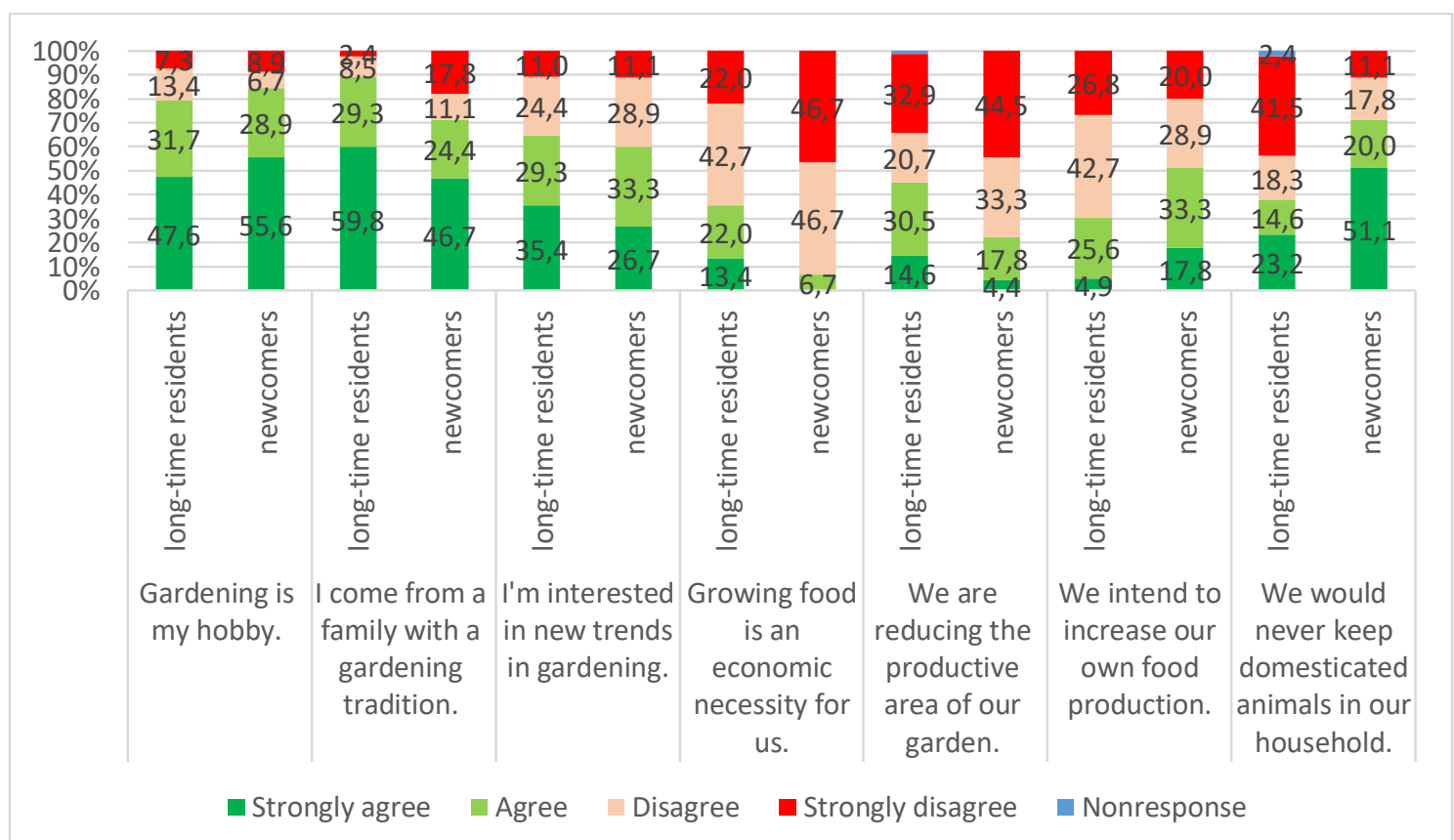

Fig 11. Attitudes towards gardening in different types of rural households (\%).

Notes: We analysed attitudes of 81 respondents from households of long-time residents (31 from the suburban region, 51 from the peripheral region) and 45 respondents from the households of newcomers (36 suburban, 9 peripheral). Source: IAEI Survey 2017 


\section{Conclusion}

Our analysis of primary data (responses gained from 178 land owners in rural South Moravia) enabled us to investigate the scope of rural FSP activities in terms of the areas of land being farmed, growing of different kinds of commodities, the character of garden maintenance, or the respondents' intentions of food production in the future.

Self-provisioning in the South Moravian rural region can be considered very widespread (cca 94\% of house dwellers produced their own food) and generally not limited in any great extent to specific social groups, although growing or producing specific commodities is associated with certain household types more often. The results from South Moravian region show practically the same information as the previous representative surveys, according to which approximately $96 \%$ of Czech population with access to land produce food. A small area of gardens is, according to respondents themselves, rarely a limiting factor for FSP in the rural Moravian region.

Although approximately the same proportion of households in both regions are engaged in growing activities, a more marked focus on productive use of gardens was seen in peripheral region households. The results of the survey in two regions with similar natural conditions but different socio-economic environments show that inter-regional differences in food self-sufficiency have a different extent in different commodities (greater differences were observed in growing commodities that can be stored easily year-round, such as potatoes, root vegetables, garlic and onions). There is also a difference between the regions in terms of the proportion of households, which keep traditional domesticated animals, mainly laying hens and rabbits (once again, more frequent in the peripheral area). By contrast, there were minimal differences in the regional comparison in growing fruit trees (the average density of fruit trees in the gardens is virtually identical), growing less frequently consumed types of vegetables and fruit (cabbage, leafy vegetables, blackcurrants, cherries, sour cherries, nuts) or growing very common types of vegetables such as tomatoes.

Inter-regional differences can be seen in the proportion of households in which FSP represents a significant boost to the family budget, whereas in the suburban region this is a minority view, households in the peripheral microregion see FSP in this way more often.

From the entire set of responses, the data show a significant difference in the extent of FSP in families of long-time residents compared to families coming to rural municipalities mostly from cities. The observed differences are thus partly reflected in the different extent of self-provisioning in both the regions.

If you visit South Moravia and look around the villages of the studied regions, you immediately feel the difference - in the suburban region, more frequently, you notice perfectly maintained lawns, while in the peripheral region, you are more likely to meet a small tractor on the road, hear the crowing of a rooster or see an older person ploughing a tiny piece of land far from ideal to work on. Our findings regarding the character of gardens and productive use of land confirm such an experience. However, some of the surveyed attitudes towards FSP in different types of households and different regions do not vary greatly. From this experience, it seems essential for the future not to limit research to very general issues (growing one's own food regardless of commodities, studying people's attitudes towards gardening regardless of its material outcomes) but to focus in detail on particular aspects of FSP such as growing herbs, keeping hens, farming on allotments, bottling fruits etc.

In both the rural regions, we find a majority of inhabitants who are interested in new trends in gardening, who have a gardening tradition within their families, view FSP as a hobby and plan to maintain the productive area of their gardens. These results might indicate great hope in the future that a drop in household food production will not be steep. However, we need to mention - based on our findings and experience - that it is material outcomes that keep many activities alive. Many of these time-demanding activities (growing potatoes or animal feed, keeping rabbits, growing on allotments, farming vineyards and producing wine, pickling gherkins etc.) continue to be more often associated with older people or long-time residents. Although households of younger people or in-migrants from towns have a great motivation to grow their own heathy food, they generally 
grow on a smaller scale, their food production includes fewer commodities and as bigger families they are generally less self-sufficient in food.

From the surveyed perspective of rural self-provisioning prospects, we can expect a general move away from work-demanding commodities and a gradual disappearance of differences in FSP in various types of households and regions, as well. This is also evidenced by CZSO data on inkind consumption in Czech rural areas and large cities.

\section{Acknowledgements}

The financial support of the Ministry of Agriculture of the Czech Republic (internal research project n. 1116/2017 of the Institute of Agricultural Economics and Information) is acknowledged.

\section{Academic references}

[1] Acheson, J. (2007). Household Exchange Networks in Post-Socialist Slovakia. Human Organization 66(4), 405-413.

[2] Alber, J. \& Kohler, U. (2008). Informal food production in the enlarged European Union. Social Indicators Research 89(1), 113-127. DOI: 10.1007/s11205-007-9224-1.

[3] Balázs, B. (2016). Food Self-provisioning - The Role of Non-Market Exchanges in Sustainable Food Supply. In Meybeck, A. \& Redfern, S., eds., Sustainable Value Chains for Sustaninable Food Systems (pp. 73-78). Rome: Food and Agriculture Organisation of the United Nations.

[4] Campbell, R. R., Spence, J. C., Amonker, R. G. (1993). The Reported and Unreported Missouri Ozarks: Adaptive Strategies of the People Left Behind. In Lyson, L., Falk, W. (eds.). Forgotten Places: Uneven Development in Rural America. Lawrence, KS: University Press of Kansas.

[5] Church, A., Mitchell, R., Ravenscroft, N., Stapleton, L. M. (2015). Growing your own: a multilevel modelling approach to understanding personal food growing trends and motivations in Europe. Ecological Economics 110, 71-80. DOI: 10.1016/j.ecolecon.2014.12.002.

[6] Cílek, V. (2016). Co se děje se světem. Kniha malých dobrodiní v časech velké proměny Země. Praha: Dokořán.

[7] Czegledy, A. (2002) Urban Peasants in a Post-Socialist World: Small-Scale Agriculturalists in Hungary. In Leonard, P., Kaneff, D., eds., Post-Socialist Peasant? (pp. 200-220). London: Palgrave Macmillan, DOI: 10.1057/9780230376427_9.

[8] Garnett, T. (2000). Urban agriculture in London: rethinking our food economy. In Bakker, N., Dubbeling, M., Gündel, S., Sabel-Koschella, U. \& Zeeuw, H. D., eds., Growing cities, growing food: urban agriculture on the policy agenda. A reader on urban agriculture 2000 (pp. 477500). Feldafing: Deutsche Stiftung fur Internationale Entwicklung.

[9] De Hoop, E., Jehlička, P. (2017). Reluctant pioneers in the European periphery? Environmental activism, food consumption and "growing your own". Local Environment, 22(7), 809-824. DOI: 10.1080/13549839.2017.1289160.

[10] Hormel, L. (2016). Food or Flowers? Dacha Gardening and Gendered Class Relations in Post-Soviet Ukraine: Food or Flowers? Rural Sociology. DOI: 10.1111/ruso.12110.

[11] Freeman, C., Dickinson, K. J. M., Porter, S. \& van Heezik, Y. (2012). My garden is an expression of me: Exploring households' relationships with their garden. Journal of Environmental Psychology, 32(2), 135-143. DOI: 10.1016/j.jenvp.2012.01.005.

[12] Felt, L. \& Sinclair, P. (1992). "Everyone Does It": Unpaid Work in a Rural Peripheral Region. Work, Employment and Society 6(1), 43-64. DOI: 10.1177/095001709261003. 
[13] Gibas, P., Matějovská, L., Novák, A., Rolfová, E., Tvardková, V., Velešová, I. \& Veselá, M. (2013). Zahrádkové osady: Stíny minulosti, nebo záblesky budoucnosti? Praha: Univerzita Karlova.

[14] Goodman, D., Dupuis, E. M. \& Goodman, M. K. (2012). Alternative Food Networks: Knowledge, Practice, and Politics. Hoboken, NJ: Taylor and Francis. DOI: $10.4324 / 9780203804520$.

[15] Guitart, D., Pickering, C. \& Byrne, J. (2012). Past results and future directions in urban community gardens research. Urban Forestry and Urban Greening 11, 364-373. DOI: 10.1016/j.ufug.2012.06.007.

[16] Jehlička, P., Grīviṇs., M., Visser, O. \& Balász, B. (2020). Thinking food like an East European: A critical reflection on the framing of food systems. Journal of Rural Studies 76, 286-295. DOI: 10.1016/j.jrurstud.2020.04.015.

[17] Jehlička, P. \& Daněk, P. (2017). Rendering the Actually Existing Sharing Economy Visible: Home-Grown Food and the Pleasure of Sharing. Sociologia Ruralis 57(3), 274-296. DOI: $10.1111 /$ soru. 12160.

[18] Jehlička, P., Daněk, P. \& Vávra, J. (2018). Rethinking resilience: home gardening, food sharing and everyday resistence. 40(4), 511-527. DOI: 10.1080/02255189.2018.1498325.

[19] Jehlička, P., Kostelecký, T. \& Smith, J. (2013). Food Self-Provisioning in Czechia: Beyond Coping Strategy of the Poor: A Response to Alber and Kohler's 'Informal Food Production in the Enlarged European Union'(2008). Social Indicators Research 111(1), 219-234. DOI: 10.1007/s11205-012-0001-4.

[20] Jehlička, P. \& Smith, J. (2011). An Unsustainable State: Contrasting Food Practices and State Policies in the Czech Republic. Geoforum 42(3), 362-372. DOI: 10.1016/j.geoforum.2011.01.005.

[21] Jensen, L., Gretchen, T. C. \& Findeis, J. (1995). Informal Work in Nonmetropolitan Pennsylvania. Rural Sociology 60(1), 91-107. DOI: 10.1111/j.1549-0831.1995.tb00564.x.

[22] Klvač, P. \& Ulčák, Z. (2008). Samozásobitelství potravinami. Může být život na venkově luxusní? In DRESLEROVÁ, J., ed., Venkovská krajina 2008 (pp. 48-51). Kostelec nad Černými lesy: Česká společnost pro krajinnou ekologii, regionální organizace CZ-IALE.

[23] Kneafsey, M., Cox, R., Holloway, L., Dowler, E., Venn, L. \& Tuomainen, H. (2008). Reconnecting Consumers, Producers and Food: Exploring Alternatives. Oxford and New York: Berg.

[24] Librová, H. (2003). Vlažní a váhaví (Kapitoly o ekologickém luxusu). Brno: Doplněk.

[25] McClintock, N. (2010). Why farm the city? Theorizing urban agriculture through lens of metabolic rift. Cambridge Journal of Regions, Economy and Society, 3(2), 191-207. DOI: $10.1093 /$ cjres/rsq005.

[26] Mcclintock, N. (2014). Radical, Reformist, and Garden-Variety Neoliberal: Coming to Terms with Urban Agriculture's Contradictions. Local Environment 19(2), 147-171. DOI: 10.1080/13549839.2012.752797.

[27] McEntee, J. (2010). Contemporary and Traditional Localism: A Conceptualization of Rural Local Food. Local Environment 15(9-10), 785-803. DOI:1080/13549839.2010.509390.

[28] Mingione, E. (1991). Fragmented Societies: A Sociology of Economic Life Beyond the Market Paradigm. Oxford, UK: Basil Blackwell Ltd.

[29] Nenashev, D. (2018). Food Self-provisioning in Russia: Case Study of Moscow and Saratov. Bachelor's Thesis, Charles University, Prague. 40 pp.

[30] Novák, A. (2013). Zahrádkářské osady v reflexivní modernitě: sociologická reflexe. In: Gibas, P., Matějovská, L., Novák, A., Rolfová, E., Tvardková, V., Velešová, I. \& Veselá, M. (2013). 
Zahrádkové osady: stíny minulosti nebo záblesky budoucnosti? (pp. 13-26). Prague: Charles University.

[31] Okvat, H. \& Zautra, A. (2011). Community Gardening: A Parsimonious Path to Individual, Community, and Environmental Resilience. American Journal of Community Psychology 47(3-4), 374-387. DOI: 10.1007/s10464-010-9404-z.

[32] Omohundro, J. T. (1995). Living Off the Land. In Felt, L. W. \& Sinclair, P. R., eds., Living on the Edge: The Great Northern Peninsula of Newfoundland. St. John's: Memorial University of Newfoundland.

[33] Perlín, R., Kučerová, S. \& Kučera, Z. (2010). Typologie venkovského prostoru Česka. Geografie 115(2), 161-187.

[34] Pungas, L. (2019). Food Self-provisioning as an answer to the metabolic rift: The case of Dacha Resilience in Estonia. Journal of Rural Studies, 68, 75-86. DOI: 10.1016/j.jrurstud.2019.02.010.

[35] Schupp, J. L. \& Sharp, J. S. (2012). Exploring the social bases of home gardening. Agriculture and Human Values 29(1), 93-105. DOl: 10.1007/s10460-011-9321-2.

[36] Schupp, J. L., Som Castellano, R. L., Sharp, J. S. \& Bean, M. (2016). Exploring barriers to home gardening in Ohio households. Local Environment 21(6), 752-767. DOI: 10.1080/13549839.2015.1017807.

[37] Sharashkin, L. (2008). The Socioeconomic and Cultural Significance of Food Gardening in the Vladimir Region of Russia [PhD thesis] Columbia: University of Missouri.

[38] Smith, J., Kostelecký, T. \&Jehlička, P. (2015). Quietly Does It: Questioning Assumptions About Class, Sustainability and Consumption. Geoforum 67, 223-232. DOI: 10.1016/j.geoforum.2015.03.017.

[39] Smith, J. \& Jehlička, P. (2007). Stories Around Food, Politics and Change in Poland and the Czech Republic. Transactions of the Institute of British Geographers 32(3), 395-410. DOI: 10.1111/j.1475-5661.2007.00258.x.

[40] Smith, J. \& Jehlička, P. (2013). Quiet sustainability: Fertile lessons from Europe's productive gardeners. Journal of Rural Studies 32, 148-157. DOI: 10.1016/j.jrurstud.2013.05.002.

[41] Sovová, L. \& Krylová, R. (2019). The countryside in the city? Rural- urban dynamics in allotment gardens in Brno, Czech Republic. Moravian Geographical Reports, 27(2), 108121. DOI: $10.2478 / \mathrm{mgr}-2019-0009$.

[42] Sovová, L. \& Veen, E. J. (2020). Neither Poor nor Cool: Practising Food Self-Provisioning in Allotment Gardens in the Netherlands and Czechia. Sustainability 12(12), Art. 5134. DOI: $10.3390 /$ su12125134.

[43] Škantová, S. (2009). Principy ekologického zemědělství v samozásobitelství na českém venkově. Prípadová studie obce Strašín na Šumavě [Mgr. Thesis]. Brno: Masaryk University.

[44] Stonawská, K. \& Vaishar, A. (2018). Differentiation and typology of the Moravian Countryside. European Countryside 10(1), 127-140. DOI: 10.2478/euco-2018-0008.

[45] Taylor, J. R. \& Lovell, S. T. (2013). Urban Home Food Gardens in the Global North: Research Traditions and Future Directions. Agriculture and Human Values 31(2), 285-305. DOI: $10.1007 / \mathrm{s} 10460-013-9475-1$.

[46] Teitelbaum, S. \& Beckley, T. M. (2006). Hunted, Harvested and Homegrown: The Prevalence of Self-provisioning in Rural Canada. Journal of Rural and Community Development 1(2), 114-130.

[47] Torsello, D. (2005). Neviditelné základy dovery. Domáca produkcia, práca a výmena na slovenskej dedine. Slovenský národopis 53(1), 5-18. 
[48] Ulčák, Z. (2006). Lookin' for Some Down-home Cookin'? A Case Study of Household Pork Production in the Czech Republic. In Kaiser, M. \& Lien, M. N., eds., Ethics and the Politics of Food (pp. 297-300). Wageningen Academic Publisher.

[49] Vávra, J., Megyesi, B., Duží, B., Craig, T., Klufová, R., Lapka, M. \& Cudlínová, E. (2018). Food Self-provisioning in Europe: An Exploration of Sociodemographic Factors in Five Regions. Rural Sociology, 83, 431-461. DOI: 10.1111/ruso.12180.

[50] Vávra, J., Cudlínová, E. \& Lapka, M. (2013). Food and sustainability: Food self-provisioning and food shopping habits in the Czech Republic and selected EU countries. In Region in the Development of Society 2013 (pp. 400-409). Brno: Mendel University.

[51] Veen, E. J. \& Eiter, S. (2018). Vegetables and social relations in Norway and the Netherlands. A comparative analysis of urban allotment gardeners. Nature and Culture 13(1), 135-160. DOI: 10.3167/nc.2018.130107.

[52] Zavisca, J. (2003). Contesting capitalism at the Post-Soviet Dacha: the meaning of food cultivation for urban Russians. Slavic Review 62(4), 786-810. DOI: 10.2307/3185655.

Other sources

[53] CZSO (2005). Retrospective Household Budget Survey for the period 1989 to 2003. [online] CZSO [cit. 21.08.2018]. Avalaible at: URL: https://www.czso.cz/csu/czso/retrospektivniudaje-statistiky-rodinnych-uctu-za-obdobi-1989-2003-n-r6nbs0a4kp.

[54] CZSO (2006, 2007). Agricultural production of households in 2006. [online] CZSO [cit. 15.08.2018]. Avalaible at: URL: https://www.czso.cz/csu/czso/zemedelska-produkcedomacnosti-2006-j5h0q3iqce.

[55] CZSO (2009-2017). Household Budget Survey for the period 2008-15. Households by municipality size and by tenure of dwelling. [online] CZSO [cit. 16.09.2018]. Avalaible at: URL: $\quad$ https://www.czso.cz/csu/czso/vydani-a-spotreba-domacnosti-statistiky-rodinnychuctu-domacnosti-podle-postaveni-osoby-v-cele-podle-velikosti-obce-prijmova-pasmaregiony-soudrznosti-2015.

[56] CZSO (2012). Basic information on the territory according to census 2011. [online] CZSO [cit. 10.09.2018]. Avalaible at: URL:https://www.czso.cz/csu/czso/scitani-lidu-domu-a-bytu2011.

[57] CZSO (2016, 2017). Small lexicon of municipalities 2015, 2016. [online] CZSO [cit. 05.08.2018]. Avalaible at: URL: https://www.czso.cz/csu/czso/maly-lexikon-obci-ceskerepubliky-2017.

[58] Unemployment statistics from a territorial point of view. Unemployment in municipalities and micro-regions of the districts Brno-venkov and Hodonín. Ministry of Labour and Social Affairs [online]. [cit. 14.08.2018]. Avalaible at: URL www. http://portal.mpsv.cz/sz/stat/nz/uzem 